AC 2007-2152: IMPLEMENTING A SIMULTANEOUS CONSTRUCTION MODEL TO EDUCATE UNDERGRADUATES IN COLLABORATION

Wenfa Hu, Tongji University 


\title{
Implementing a Simultaneous Construction Model to Educate Undergraduates in Collaboration
}

\begin{abstract}
One of the goals in Construction Management is to educate students to become successful construction managers who need both technical knowledge and management skills. But most of Construction Management programs teach students techniques or management separately, and then students can not understand abstract construction management skills easily without practices. A Simultaneous Construction Model based on online collaboration and 3D visualization is presented in this paper, and on this model students work together effectively from design phase through construction phase in several cases. From this model, students learn how to collaborate in construction engineering.
\end{abstract}

\section{Introduction}

Construction management is a comprehensive knowledge which includes techniques and practices, and construction techniques concern not only civil engineering techniques such as properties of materials, structural engineering method, and soil mechanics, but also other relevant engineering techniques such as air conditioning, plumbing, electrical systems, and elevators. As majority of undergraduates begin to study construction management without any previous construction practices, they have time on neither studying through all relevant construction techniques or management skills nor practicing through construction projects within 4 years. Students often feel frustrated when they try to illustrate how a construction project is managed and what construction participants communicate.

One goal of Construction Management Program is to make students become successful construction managers who are capable of solving both common and unusual problems. But construction management problems usually are tangled with techniques with management issues, students must learn how to use both technical and management skills to manage construction projects properly. Usually undergraduate students learn basic civil engineering techniques in the first two years, and then they learn some abstract management skills such estimation, quality management, project management in the last two years. Since those management courses are self-independent, few practical construction management skills are taught in classes. Majority of Construction Management programs teach students techniques or management separately, and then students can not understand abstract construction management skills easily without practices. Though students can learn more construction communication skills by simple cases in classes, a construction project is too complex to study in any time-limited course ${ }^{4}$. 
In order to make undergraduates understand how construction management and communication are going on, this paper presents a simultaneous model based on 3D construction models and online communication model to help them.

\section{Participants of a Construction Project}

There are usually more than 20 teams in a moderate construction project. An undergraduate student can hardly understand their complicated relationships and collaboration from textbooks ${ }^{2}$. Though teachers should mention construction project organization method in several courses, students seldom learn a full-scale construction organization, and students never learn how to choose suitable communication techniques and to collaborate efficiently with others in a full-scale construction project ${ }^{3}$. Because there are so many different types of construction project deliveries and organizations that students can not study all of them in one or two courses. In practices there are usually only one or two dominant construction project organization structures, for example the traditional construction management approach is well accepted and can be used in this paper.

\section{Construction Project Organization}

Traditional construction management approach is broadly adopted in current Chinese construction industry though a real project organization may be different from popular methods such as FIDIC, RICS, or others ${ }^{1}$. There is a typical traditional construction project organization sponsored and managed by local companies, shown in Figure 1, students should study it carefully at first and then choose a role.

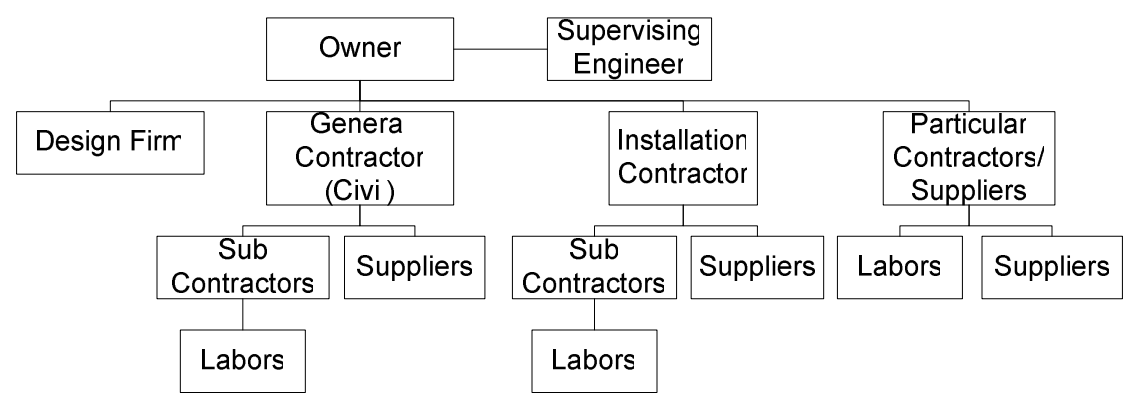

Figure 1 A Typical Traditional Construction Organization Structure

Usually the project owner is more important in selecting the construction organization structure. If the owner wants to control every procedure and project goals such as the cost, time, quality, and scope, he will hire more staff such as professionists in his temporal team. It is widely observed that a project owner adopts a projectized organization structure in a moderate or large building project, and the owner has to establish a full functional team to undertake the project management duties. A structure of owner's projectized organization is shown in Figure 2. 


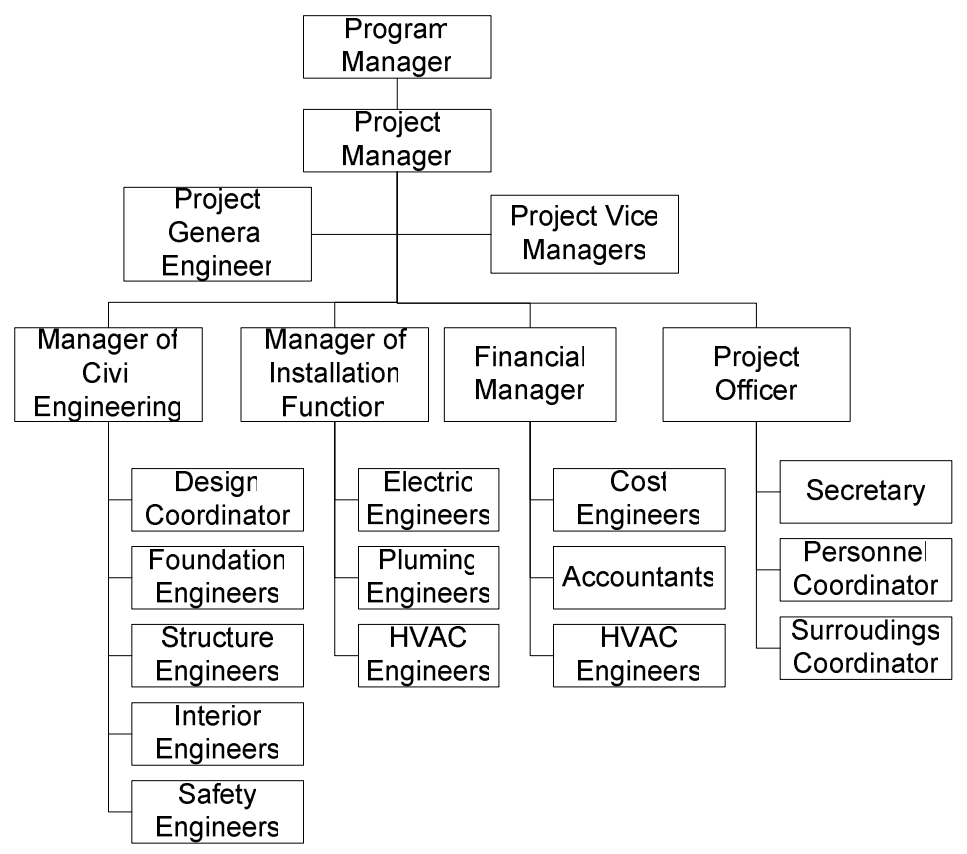

Fig. 2 The Projectized Organization of The Owner in a Building Project

The project owner might divide the project into several packages and assign those packages to several contractors by competitive bidding. Every construction contractor establishes a organization structure to provide services and/or goods for the owner. Students can be asked to develop several organization structures for the civil engineering general contractor, the sub-contractor of piles or foundations, the particular contractor of curtain installation or elevators, the supervising engineer, and the design firm.

According to Chinese construction laws and regulations, the owner must hire a supervising engineer company as his deputy who monitors and controls construction quality on site and this is very different from other countries. Sometimes owner transfer more responsibilities of construction management including schedule management and cost control to the supervising engineer, but owners would like transfer the responsibility of cost control to a cost engineer rather than a supervising engineer since construction cost engineers are gradually accredited by formal institutions. A supervising engineer is obligatory in most construction projects, but a cost engineer is not. But now cost engineer is more popular as a consultant of project owners.

\section{Classification of Construction Project Participants}

In order to make students understand the roles and responsibilities of different construction project participants, the participants are classified as:

(1) Owner (Company). The owner is a project's client or sponsor or developer, which is responsible for buying the project from construction contractors. 
(2) General Contractor (civil engineering) (Company). A general contractor of civil engineering usually undertakes the whole civil engineering management services from the owner and he may transfer parts of those services to sub-contractors with the permission of the owner and the supervising engineer. A general contractor of civil engineering is only a management company which has more managers rather than workers or labors.

(3) General Contractor (Installation) (Company). A general contractor of installation is usually responsible for all installation duty such as electric, plumbing, HVAC, elevator, fire control, telephone, cable and so on. He is also a management company which need buy equipments and labors from others.

(4) Sub-Contractor (Company). There are many different kinds of sub-contractors in a construction project. In China there are 66 kinds of special and particular construction companies which can compete for contracts from owner directly or from general contractors. But a sub-contractor has to fulfill his duty by himself or with helps from labor companies. It is illegal for a sub-contractor to transfer any parts of his construction duty to any other one.

(5) Supplier (Company). There are many suppliers in a construction project and they provide construction materials, temporal tools, equipments, and others. Suppliers are the key factor in construction schedules and cost and performance. Sometimes owner would buy construction materials or equipments directly from suppliers, and sometimes contractors do it.

(6) Construction Labor (Company). Construction labors should be chosen by contractors from construction labor companies, and there is usually a labor leader in labor teams to negotiate and bargain with construction contractors. Construction labors do not establish a direct contract relationship with the owner or other participants but with general/sub contractors. Chinese construction labors and their leaders are usually lack of formal educations and come from countryside.

(7) Design Firm (Company). A common design firm is usually large and the architects, civil engineers and other engineers are included in the same design firm.

(8) Supervising Engineer (Company). Supervising engineer in China is similar to the Engineer in FIDIC contract conditions, and he is very important in monitoring construction processes in site.

(9) Cost Engineer (Company). Cost engineer calculates quantities of the project and checks any construction bills which contractors submit. Though the independent cost engineer company can be a consultant of the owner, cost engineers are observed in other teams.

(10) Government Departments. All construction activities from preliminary design through 
completion check should be under monitoring of government departments. And also construction companies and individuals should apply for permissions or licenses from government departments.

Personnel of construction management could be classified as below according their disciplines: (1) civil engineer (soil/foundation engineer, surveyor, structure engineer and so on); (2) architect; (3) construction schedule engineer; (4) construction cost engineer; (5) construction safety engineer; (6) construction quality engineer; (7) supervising engineer; (8) electric engineer; (9) mechanical engineer; (10) staff and secretary; (11) construction labors (civil engineering); (12) construction labors (plumbing); (13) construction labors (electric engineering); (14) construction labors (decoration); and others.

\section{Assignment of Construction Teams among Students}

The roles of construction participants would be assigned to students in a simulated building project, and students could pretend to be engineers, staff or labors and should study knowledge and skills relevant to their roles. Assignment of roles is shown in Figure 3.

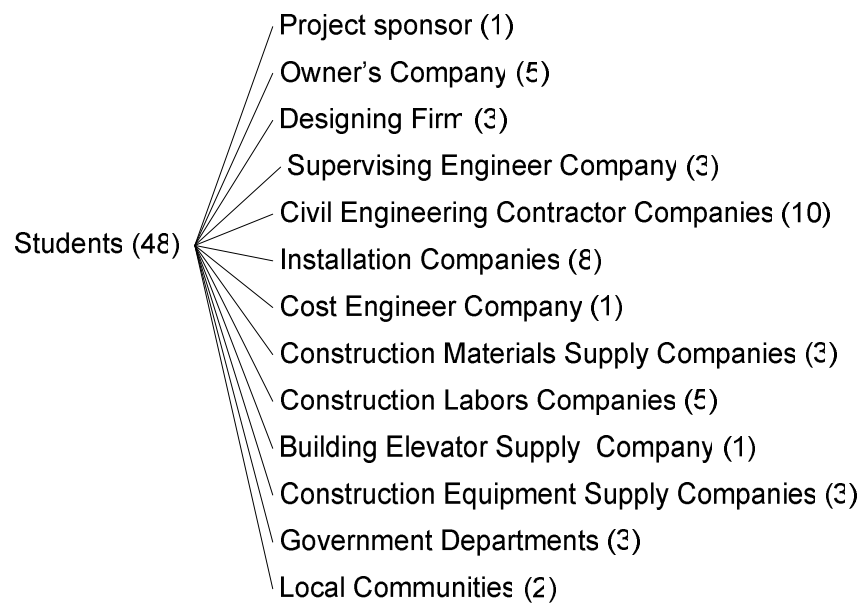

Figure 3 Assignment of roles to 48 students in a class

Any student would be on duty of a certain role in a company. The students will learn the background of his role in the company by duty description, working time, salary, working condition. Then students can decide how to react in construction collaboration.

\section{Collaboration among Construction Teams}

There are a lot of expected and unexpected problems in the construction projects. Since there are so many participants in the project that they may conflict fiercely with each other, because one team cares his own interests more than project goals or any others' interests. One purpose of construction collaboration is to help participants communicate construction information 
effectively and find ways to solve any potential or practical problems before, during and after construction.

\section{Typical Construction Information}

There are many potential problems if construction teams are lack of sharing construction information with each other. Construction information can classified as (1) physical information, for example climates, construction site, and underground water of site; (2) technical information, for example shop drawings, construction specifications, construction planning, construction methods and technologies; (3) management information, for example construction contracts and regulations, construction schedules, management procedures, and construction quality; (4) social information, for example cultures, religions, educations, and moral standards; (5) economical information, for example salaries, materials prices, payments, and claims; (6) other information.

Construction technical and management information is more important than other information, and construction engineering information is difficult to be communicated among project participants because construction technical specifications need to be interpreted precisely by all participants, but construction drawings are only lines which are abstract. In order to make all well-educated and non-educated members understand construction information without bias, it is

helpful to use modern approaches to explain construction information ${ }^{12}$. If abstract technical information can be explained by documents, 3D visualizations, and database, construction collaboration would be more effective, and misunderstanding, misinterpretation, or wrong actions would be reduced dramatically.

\section{Construction Information Flows and Collaboration}

Construction information flows reflect how construction teams communicate with each other. Reasonable information flows can reduce collaboration conflicts. There are many formal construction information flows based on project contracts, and also there are many informal construction information flows which are formed among some teams based on personnel or work relationships. If there are lack of formal regulations to manage construction information flows, students in the simulated construction project would be in chaos and no collaboration forms, and then few significant progresses are made. Construction communication directions are shown in Figure 4. 


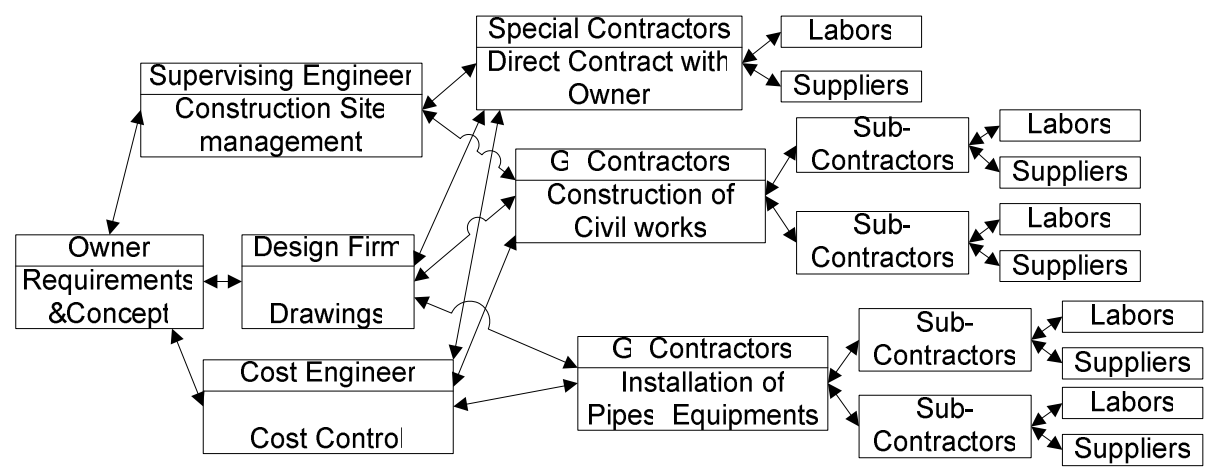

Figure 4 Construction information flow in collaboration

\section{A Simultaneous Construction Model}

Traditional construction communication tools are reports or meetings which are accepted broadly by all teams. But traditional construction communication tools are not efficient in interpreting the advanced and abstract construction techniques, and are also expensive in communication.

In the construction projects, students try to find out effective communication tools to collaborate and negotiate with each other to solve construction problems, especially technical problems. Though majority of construction teams regard emails and MSN as important communication tools and prefer to use them, many students think them are not effective in construction information management. When some students do not check or reply emails promptly, the communication becomes unstable and tardy, communication efficiency is very slow.

\section{Building Information Model and Construction Communication}

A building information model can depict real elements of a building, and it is able to list, analyze, quantify, manipulate and view the resultant data instantaneously and with perfect accuracy relative to the CAD drawing 9 . Enter a number or an element one time, and then use that information to analyze, quantify and compare the data in a multitude of ways ${ }^{10}$. Elements in a 3D drawing can be represented in plan view, section or elevation. Each element is drawn only once, but the element can be viewed and evaluated in many ways ${ }^{11}$. The users of the building information models can properly position in real 3D space to provide additional data to each element, since the drawing is in actuality a simulation of the building project. So the building information model is a perfect and effective tool in construction communication ${ }^{14}$. Students are grouped and use the Building Information Model in communication shown in Figure 5 where the building is a 3D construction project that students have studied. 


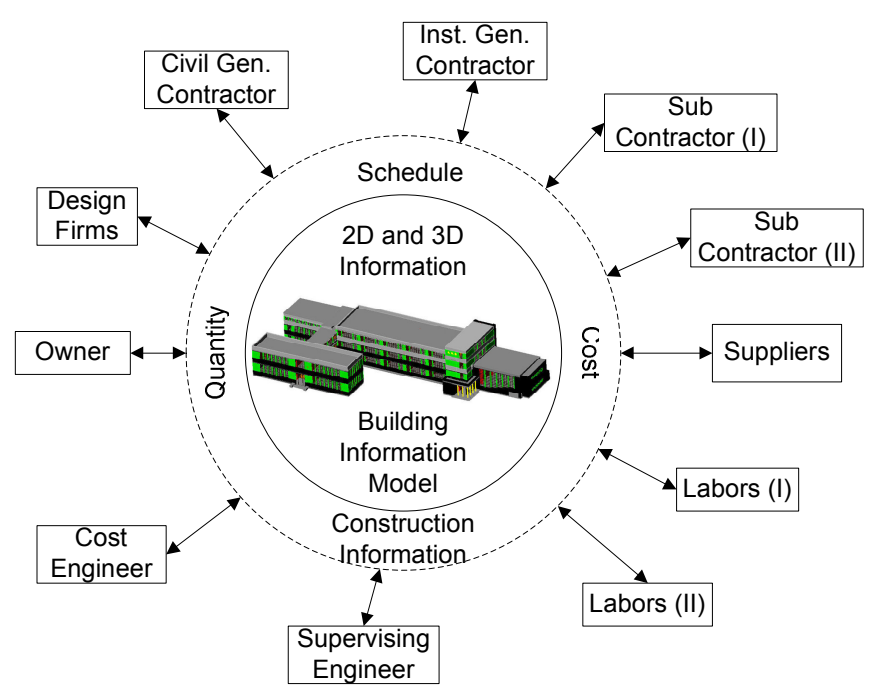

Figure 5 Construction Communication in the building information model by students

There are now several vendors, for example Autodesk, Graphisoft, Benterley, in the market that produce affordable software for development of the Building Information Model ${ }^{13}$. A joint lab between Autodesk and the department of construction management at Tongji University provides free use of the software (Revit, Civil 3D, AutoCAD, Buzzsaw and others), technical support, and professional collaboration. Students have developed several buildings and construction information models in this joint lab rapidly because now BIM software is more productive than others in construction industry.

It is more efficient for all participants to collaborate in construction in the building information model than traditional method, because (1) any team members could access the building information and construction information after authentification, or (2) if a team member creates, modifies or deletes an element or any datum in the information model, the whole model would be changed simultaneously and other participants would be informed immediately. Those merits are very useful for users to reduce frequency of checking building information that redundant check would just waste users' time.

\section{Combination of Building Information Model and Internet-based Collaboration}

Construction information is very complex since it needs more independent teams in a construction project than any other project, and a project team can do nothing if without collaboration with other teams. Construction information can be categorized as Construction Technical Information such as building drawings and construction techniques and Construction Management Information such as reports, instructions and controls. The building information model could be a useful solution for project teams to collaborate on construction technical information, and internet-based collaboration model could a useful solution for project participants to collaborate on construction management information, shown in Figure 6. 


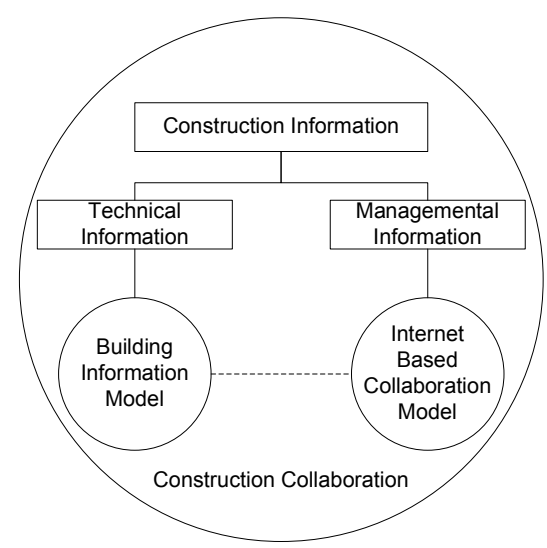

Figure 6 Construction Information Category and Collaboration Models

\section{Internet-Based Construction Collaboration Model}

With the help of the Internet-Based Construction Collaboration Model, construction projects are being managed far more efficiently in regards to time and expense than ever before ${ }^{5}$. Construction team members can recoup the cost of the service in most cases rather quickly ${ }^{7}$. The internet-based construction collaboration model has made an indelible mark on the way owners, architects and contractors work in partnership to complete projects on time and within budget.

We suggest students adopt Autodesk Buzzsaw as the internet-based construction collaboration tool. Buzzsaw incorporates a number of sophisticated reporting, task assignment and project tracking features for active, real-time project management, and all participants can be assigned different permissions when they collaborate in the project, an example is shown in Figure 7.

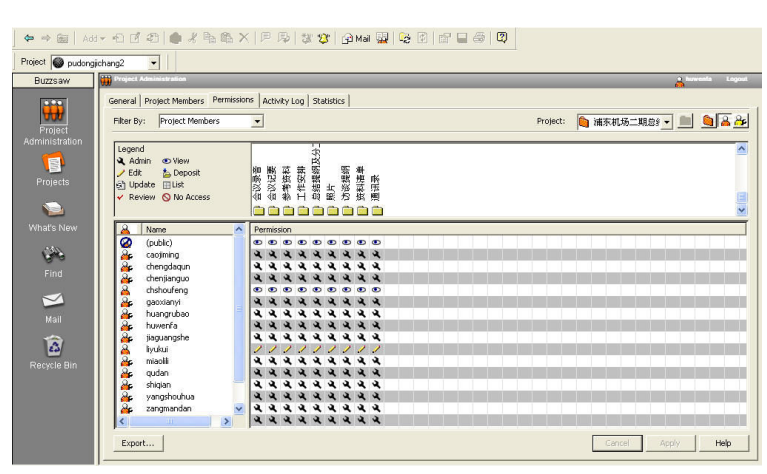

(a) Assignment of permissions of members

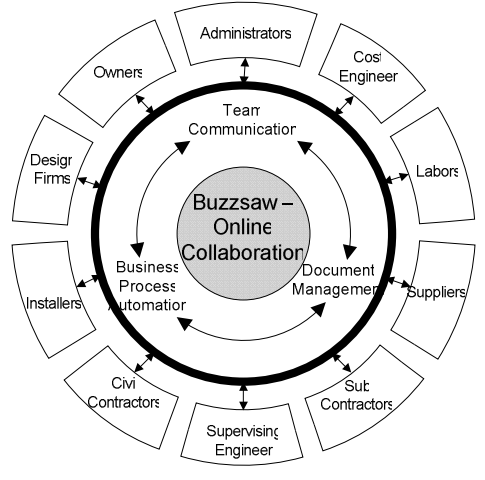

(b) Collaboration of Participants in Buzzsaw

Fig. 7 Assignment of permissions of construction teams in Buzzsaw application

Project team managers can track project status on the basis of individual team members and generate customized reports that leverage critical information to deliver valuable insight into building projects. These features help all team members promote precise communication and more efficient project management, regardless of location ${ }^{8}$. 
Buzzsaw provides enhanced control over construction processes and improved collaboration for all team members during design, bidding, procurement, and construction. All of project documents, including design drawings, bid documents, construction RFIs, submittals, and meeting minutes, are centralized for easy access at any time (only if the web servers are maintained well). All team members get the right information at the right time. Having the entire construction participants working on Buzzsaw enables consistency across the board, saves printing and distribution costs, reduces the need for travel, and lowers the incidence of planning and construction errors attributable to outdated information.

\section{Student Projects}

Students use gradually the Building Information Model in developing building projects and in communicating technical information and the Internet-Based Construction Collaboration Model in communicating management information. One largest project is Tongji Campus where several new buildings facilities are designed and constructed from 2004 and several old buildings facilities are under revamp now. Students take parts in design, general construction, installation, furnishing, coordination and other jobs of the campus project. A 3D-based building information of Tongji University developed by students is shown in Fig. 8.

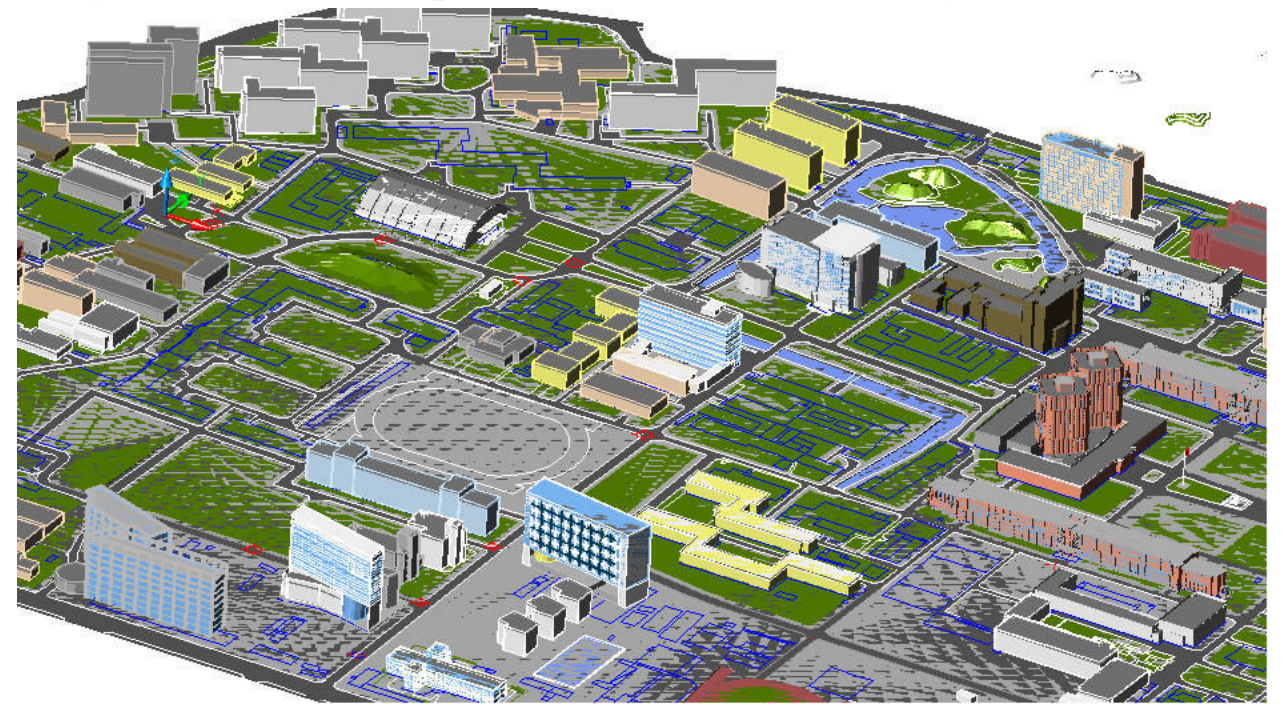

Figure 8 3D-based building information of Tongji University Campus

\section{Students Learning Assessment}

Students learning assessment data about this construction model was collected in end of the semester, 32 students committed the survey. The assessment criterion is classified as Excellent (5.0), Well done (4.0), Acceptable (3.0), Unacceptable (0.2). After analysis, the students learning assessment report is shown in Table 1. 
Table 1 Students learning assessment report

\begin{tabular}{|l|l|l|l|l|}
\hline \multirow{2}{*}{ Assessment Item } & \multicolumn{4}{|c|}{ Criterion } \\
\cline { 2 - 5 } & $\begin{array}{c}\text { Excellent } \\
(5.0)\end{array}$ & $\begin{array}{l}\text { Well done } \\
(4.0)\end{array}$ & $\begin{array}{c}\text { Acceptable } \\
(3.0)\end{array}$ & $\begin{array}{c}\text { Unacceptable } \\
(0.2)\end{array}$ \\
\hline $\begin{array}{l}\text { Ability to develop construction } \\
\text { management skills. (0.15) }\end{array}$ & 20 & 8 & 3 & 1 \\
\hline $\begin{array}{l}\text { Understanding of construction } \\
\text { participants. (0.10) }\end{array}$ & 26 & 3 & 2 & 1 \\
\hline $\begin{array}{l}\text { Construction collaboration skills. } \\
(0.20)\end{array}$ & 25 & 4 & 2 & 1 \\
\hline $\begin{array}{l}\text { Grasping construction techniques. } \\
(0.15)\end{array}$ & 22 & 5 & 3 & 2 \\
\hline Application of CAD. (0.10) & 27 & 3 & 2 & 0 \\
\hline $\begin{array}{l}\text { Using internet-base communication. } \\
(0.10)\end{array}$ & 27 & 4 & 1 & 0 \\
\hline $\begin{array}{l}\text { Efficiency of learning and using this } \\
\text { model. (0.10) }\end{array}$ & 18 & 10 & 2 & 2 \\
\hline $\begin{array}{l}\text { This model is useful in construction } \\
\text { industry. (0.05) }\end{array}$ & 24 & 5 & 3 & 0 \\
\hline Willing to use it next time. (0.05) & 23 & 6 & 2 & 1 \\
\hline Overall assessment & 4.6 & \multicolumn{3}{|l|}{} \\
\hline
\end{tabular}

The report reveals that majority of students have learnt how to collaborate in construction projects and acquired both management skills and technical knowledge from this model. The report also reveals students can learn some IT tools of CAD and Internet communication from the model, and the model is easy to be used in construction practices. Overall assessment score is 4.6, which means this model is well accepted by students and they are satisfied with this kind of education.

\section{Conclusion}

This paper describes the construction project organization and communications among project participants and implements simultaneous collaboration applications based on the Building Information Model and the Internet-Based Construction Collaboration Model that research is conducted at Tongji University. It also examines new technology in the current and future education and professional practice of construction engineering and management. This research reveals that construction management practice requires construction technical and management skills, and construction management education requires constant revisions to adopt the emerging technologies. The results of this paper show that the simultaneous construction model is much better to educate students in the complicated construction collaboration, since the Building Information Model provides students with a tool for rapid visualization of the building and allows them to develop a more integrated view and better understanding of the building and its 
components and of the design and construction process and the Internet-Based Construction Collaboration Model enables more effective and precise communication and efficient management of all construction information among all participants.

Simulated and real construction projects help students to actively engage in the process of project planning, design, and interpretation of construction data, to make students to effectively involve in sharing, communicating and solving construction problems. Students learn much more from this construction model than books. Though students did not experience construction before, they have grown up in construction management and accept the notion of cooperation. Also students have understood the different characteristics and interests of construction participants. This simultaneous construction model is a new technology and equips students with advanced skills to successfully achieve progresses in construction industry after graduation.

Finally this model teaches students in a short time how to use the effective software and understand the key technical problems of buildings.

\section{Bibliography}

1. Tianji Xu, Smith, N.J.; Bower, D.A., "Forms of collaboration and project delivery in Chinese construction markets: Probable emergence of strategic alliances and design/build", Journal of Management in Engineering, v 21, n 3, July 2005, p 100-9.

2. Stroupe, A., Huntsberger, T.; Okon, A.; Aghazarian, H.; Robinson, M., "Behavior-based multi-robot collaboration for autonomous construction tasks", 2005 IEEE/RSJ International Conference on Intelligent Robots and Systems, 2005, p 1495-500

3. Kirisci, P.T., Hunecke, H.-H.; Hribernik, K.A.; Dikici, C., "A wireless solution for mobile collaboration on construction sites", 2004 International Workshop on Wireless Ad-Hoc Networks (IEEE Cat. No. 05EX789), 2004, p 166-71

4. Ingirige, B., Sexton, M., "Alliances in construction: investigating initiatives and barriers for long-term collaboration", Engineering Construction and Architectural Management, v 13, n 5, 2006, p 521-35

5. van Leeuwen, J.P., van der Zee, A., "Distributed object models for collaboration in the construction industry", Automation in Construction, v 14, n 4, Aug. 2005, p 491-9

6. Faraj, I., Alshawi, M., "Global project collaboration in the construction industry: standardisation and integration", International Journal of Computer Applications in Technology, v 20, n 1-3, 2004, p 26-41

7. Pena-Mora, F., Anumba, C.J.; Solari, J.; Duke, A., "An integrated telepresence environment for collaboration in construction”, Engineering with Computers, v 16, n 3-4, 2000, p 287-305

8. Benbunan-Fich, R., Arbaugh, J.B., "Separating the effects of knowledge construction and group collaboration in learning outcomes of web-based courses", Information and Management, v 43, n 6, Sept. 2006, p 778-93

9. Garcia, A.C.B., Kunz, J.; Ekstrom, M.; Kiviniemi, "Building a project ontology with extreme collaboration and 
virtual design and construction", Advanced Engineering Informatics, v 18, n 2, April 2004, p 71-83

10. Soibelman, Lucio, Caldas, Carlos, "Information logistics for construction design team collaboration", Computing in Civil and Building Engineering, v 1, 2000, p 341-348

11. El-Gohary, Nora M., El-Diraby, Tamer E., "A framework for inter-organizational collaboration in infrastructure and construction using lattice algebra”, Proceedings, Annual Conference - Canadian Society for Civil Engineering, v 2005, Proceedings - 33rd CSCE Annual Conference 2005: 6th Construction Specialty Conference, 2005, p CT-110-1-CT-110-11

12. Jiang Guichuan, Fan Yusun; Wu Cheng, "Time and cost-based analysis of dynamic collaboration construction", Journal of Tsinghua University (Science and Technology), v 42, n 3, March 2002, p 391-5 Language: Chinese

13. Fox, C. and Balding, J., "Introducing and implementing Autodesk Revit ${ }^{\circ}$ Building", Thomson Delmar Learning, NY, 2006.

14. Wiezel, A., Walsh, K., Brena, J., "A Critical Analysis of an Introductory Computer Course for Constructors" Journal of Construction Education, Spring 1999, Vol. 4, No. 1, pp. 39-49. 